\title{
Sanitation and risks of waterborne diseases in Aholouyèmè in the commune of Sèmè-Kpodji (BENIN, West Africa)
}

\author{
1,3Marc SOHOUNOU, 2,3Expédit Wilfrid VISSIN, 2,3Gervais A. A. ATCHADE, ${ }^{1}$ Patrick A. EDORH \\ ${ }^{1}$ Biochemistry and Cellular Biology, University of Abomey-Calavi (UAC), BP 2899 Abomey-Calavi, Benin \\ 2 Laboratory Pierre PAGNEY: Climate, Water, Ecosystems and Development, University of Abomey-Calavi 01 BP \\ 526, Cotonou \\ ${ }^{3}$ Department of Geography and Regional Planning, Faculty of Letters, Arts and Humanities, University of Abomey- \\ calavi, BP 2899 Abomey-Calavi, Benin \\ Mail: borismarcs@gmail.com
}

Original submitted in on $17^{\text {th }}$ February 2016. Published online at www.m.elewa.org on $30^{\text {th }}$ April 2016 http://dx.doi.org/10.4314/jab.v100i1.5

\begin{abstract}
Objective: The present study aims to analyze the risk of diseases related to bad conditions of sanitation in the district of Aholouyèmè, in Benin.

Methodology and Results: To achieve this goal, a statistical approach was adopted. The methodological process implemented documentary research, field survey through observation, investigations using questionnaire, interview guide and data analysis at laboratory.

In order to understand the degree of pollution, some hydraulic infrastructures (wells) were sampled. The samples were analyzed in the laboratory of the control of Food Safety at the ministry of Agriculture in Benin. After fieldwork, the data was analyzed.

Conclusion and application of results: Field investigations showed that the water wells dug in each village by The Head Office of Water (Ministry in charge of water and mines) are not functional any more. In addition, there was no water point installed by National Society of Waters in Benin. All sampled wells were microbiologically polluted. The presence of the faecal coliforms, streptococci and $E$. coli revealed a faecal contamination of water. Consequently, water from those wells was not safe for human consumption. Many waterborne diseases such as intestinal parasitosis, febrile diarrhoea and cholera prevailed in the district. The origins of this pollution were multiple. It can be cited bad garbage management, absence of latrine, lack of sanitation around wells, non-respect of hygienic rules.
\end{abstract}

Key words: Aholouyèmè, sanitation, pathologies, drinking water, risks.

\section{INTRODUCTION AND JUSTIFICATION}

The problem of drinking water is critical in African countries in general and those of West Africa in particular. Essential for all living being, potable water is less available in its quality. (Sohounou, 2012)
The potential water of rivers in Benin is globally estimated to 13 billion cubic meters per year but its use is insignificant. Benin has significant water resources that would meet the demands in medium 
and long term (MMEH, 2005). Unfortunately, the current system of working and management of natural resources represent serious threats to the protection and preservation of water resources and consequently the survival of future generations (Yélognissè, 2007). The United Nations (UN, 2005) estimated that among the 37 major diseases in developing countries, 27 are related to water. In the least developed countries, 15 million children die every year from contaminated drinking water, poor hygiene and malnutrition. WHO (1994) estimated that $80 \%$ of all diseases are related to a nutrition with dirty water and inadequate sanitation. Drinking water remains in the early twenty-first century an inaccessible good for a large portion of the world population (MMEH, 2005). That report was the same in the district of Aholouyèmè in Benin. In addition, the existent water points were unsanitary. Those water points are traditional wells and boreholes constructed by the hydraulic office of Benin. They were not functional at all. Therefore, the majority of people consumed water from unprotected wells.
Moreover, the conditions of collection, transport, storage and handling of water can become sources of contamination, and could be the basis of waterborne diseases (Sohounou, 2012). SèmèKpodji, like other cities of Benin, was not provided with drinking water. Accessibility and availability of supply were not the same in a rural or urban areas (INSAE, 2002). Despite efforts done by the government and Sémè-Podji town hall, drinking water is a problem in some districts of the Commune. The district of Aholouyèmè, which is our study area, has no supply equipment of drinking water. The relief of the study area is very low, composed of fine sand, water bodies and some swamps. The district of Aholouyémè (Figure 1 ) is geographically located between parallels $6^{\circ} 30^{\prime \prime}$ to $6^{\circ} 35^{\prime \prime}$ north latitude and $2^{\circ} 30^{\prime \prime}$ to $2^{\circ} 35^{\prime \prime}$ east longitude. It is bounded in the north by the lagoon of Porto-Novo, in the east by the district of Djrègbé, the south by the district of Ekpè and Sèmè-Podji and in the west by Lake Nokoué (Slansky, 1995).

CARTE ADMINISTRATIVE DU BENIN

COMMUNE DE SEME-KPODJI : Localisation de la zone d'étude

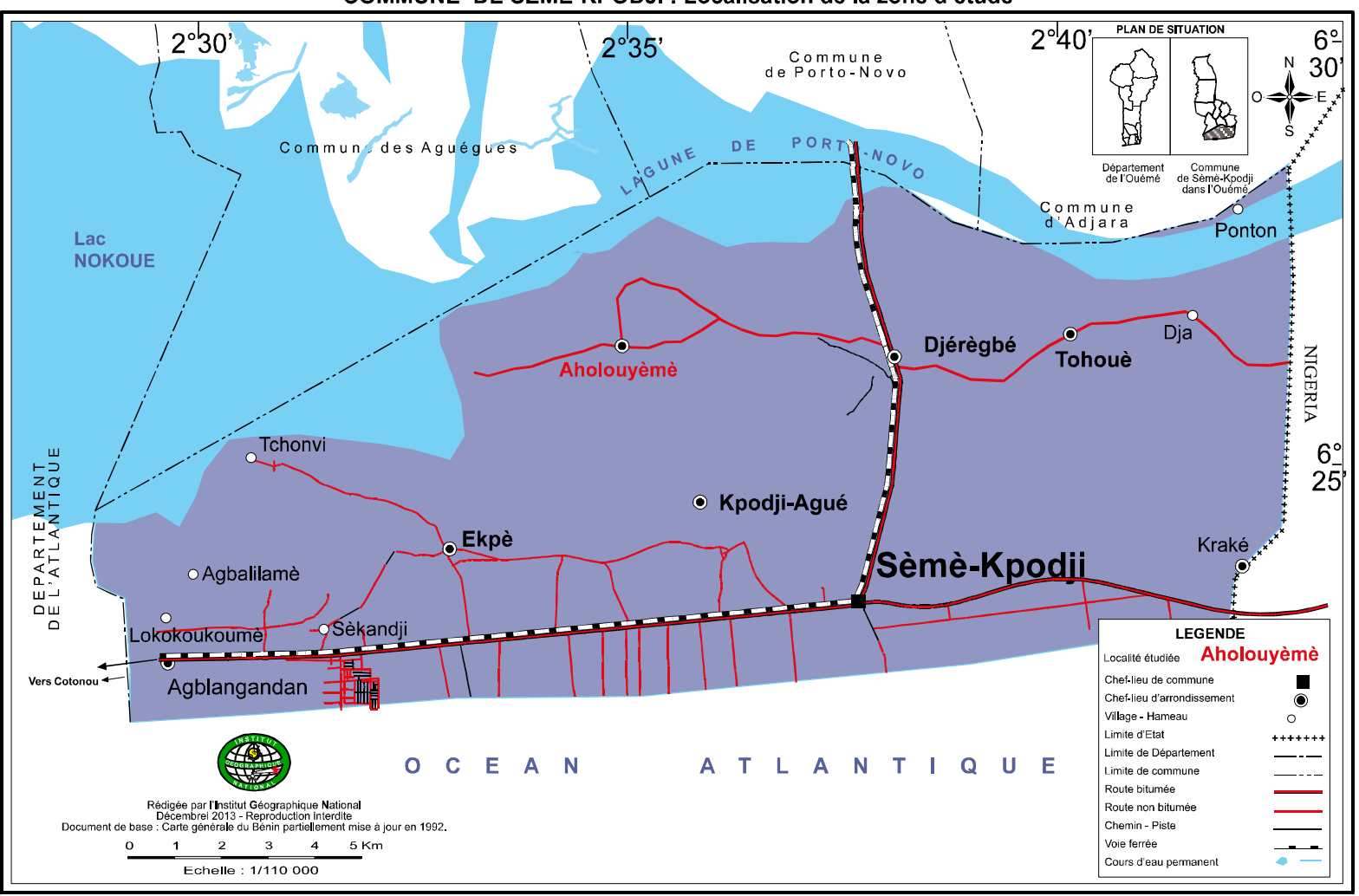


Figure 1: Location of the study area (Aholouyèmè in the commune of Sèmè-Kpodji)

\section{MATERIALS AND METHODS}

Data on the subject of research was collected through the following tools and techniques: documentary research, questionnaire, interview guide and interviews. It was socio-anthropological data, quantitative data on the population of Aholouyèmè obtained at INSAE; the sampling rate is $15 \%$. The data processing resulted in data crossing and working out of statistical tables. Illustrative photographs of various facts were also

\section{RESULTS AND DISCUSSIONS}

Mode of sanitation: By taking into account observations and results of investigation, sanitation around water points, management of the household waste and used water, the management of excreta constitutes a major problem in the study area.

Sanitation around water points: Water supply and sanitation are two concerns that go together. Very often, selected. Figures and calculations were performed using Excel and Word software. As for the results from the processing of data, it was to describe, comment and interpret the various figures and statistical series to highlight the evolution in space and time of observed variables. All those process have yielded the following results.

the potable water supply programs are followed by sanitation, such as the National Strategy of Water Supply in Rural Area in Benin. However, in Aholouyèmè, the sanitation is not a concern. Photo 1 shows the state surrounding the wells whose water is highly appreciated by the people in the study area.

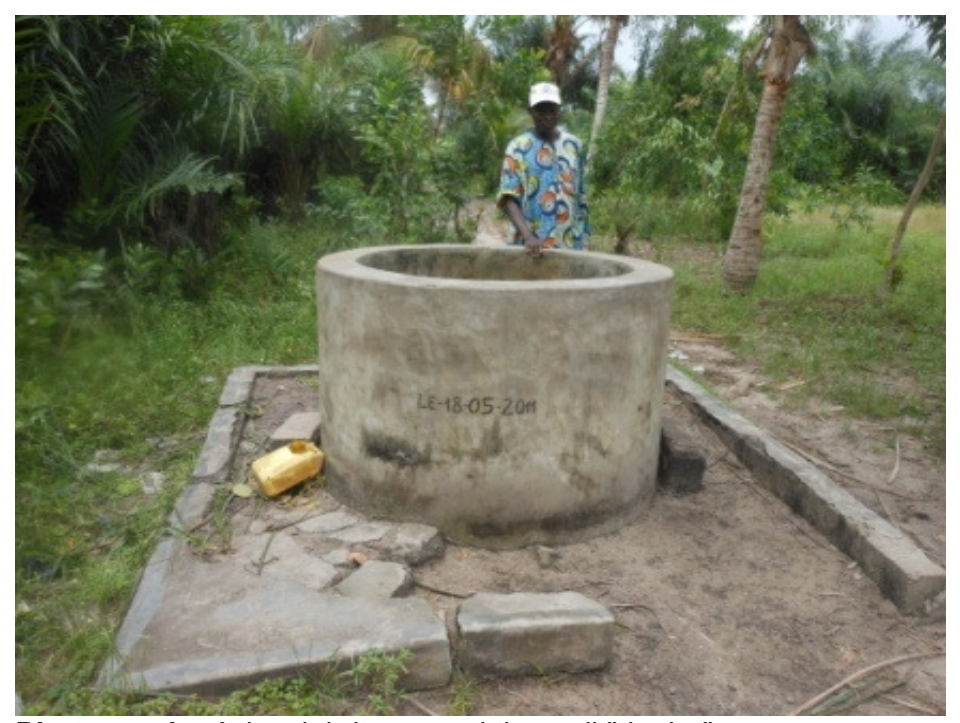

Photography 1: insalubrity around the well "dogbo"

Camera work: DEGBENOU, August 2013

Looking at the photograph 1 , it is clear that sanitation around water points is not a major concern for the entire population of Aholouyèmè. As result, all water points, modern or traditional, suffer from problems of maintenance.

Management of household wastes: The evidence of waste management is not yet well perceived by almost all of the population of our study area. Bad practices of the population in relation to the proper disposal of garbage still create a lot of harm to the environment and human health. The methods of disposal of such waste in the district of Aholouyèmè vary widely: they are thrown in the nature or wild discharge (empty land) $(68.7 \%)$, in the yard of the house $(28.5 \%)$ and sometimes incinerated outdoor $(2.8 \%)$. There are no services or NGOS for collection and disposal of garbage as is the case in some major cities of Benin. The degradation of the water quality, the surrounding infrastructures and the water stored in uncovered containers are considerable. Indeed, uncovered containers are infested by flies, germs and bacteria from the garbage heap. These deposits of 

commune of Sèmè-Kpodji (BENIN, West Africa)

microbes in the water cause health hazards to the uninformed populations.

Management of wastewater: Domestic wastewater comes from bathing, dishwashing, laundry and kitchens. Among respondents, $75 \%$ of households discharge wastewater in the yard or behind the house; $25 \%$ use a pit outside the house. Wastewater is composed of pollutants whose impacts on the environment are variable. Improper disposal of these waters can cause considerable nuisance and health risks. They can also indirectly affect health by creating favourable conditions for mosquito breeding. These waters, on the ground, can form mud, creating an environment favourable to the survival of pathogens. Those can quickly contaminate well water during bailing or transport and therefore will cause the spread of infection. Children are particularly vulnerable to infections when they play.

Management of the excreta: All urines and human excrements constitute the excreta. The evacuation of the excreta leads to the contamination of the grounds and the sources of supply water. The Figure 2 shows the proportion of the surveyed people who use the infrastructures of ease.

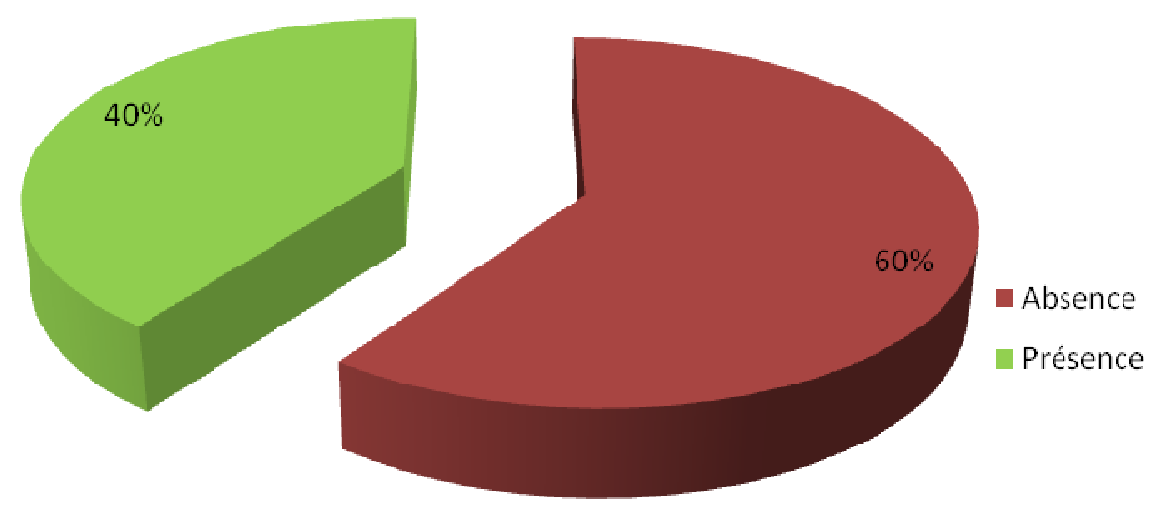

Figure 2: Use of infrastructures of ease

Source: Field investigations, September 2013

Analysing the Figure 2, 60\% of people defecated in nature and $40 \%$ use non-waterproof traditional latrines. Moreover, houses that had latrines were at risk of faecal peril because of poor hygiene practices. Indeed, latrines were not cleaned regularly. There were excreta on the edges of some latrines where some insects sat especially flies. Note also that the pits were not deep and became full quickly. Those badly evacuated excreta were accessible to animals and flies. Flies would invade the water points and the risk of contamination would be high. Appreciation of the quality of water available for the population and waterborne diseases: It is significant to evaluate the opinion of the population on the quality of the water that they drink on one side. On other side, it will be evaluated the microbiological quality in order to apprehend the risks of waterborne pathologies.

Appreciation of the quality of the drinking water available for the population of the district of Aholouyèmè: Field surveys were used to collect the assessments of populations on some organoleptic parameters of water from five (5) identified wells. Table 1 presents the assessments of populations on the characteristics of the water drunk in the district of Aholouyèmè. 
Table 1: Criterion of appreciation of water quality by the population

\begin{tabular}{|l|c|c|c|c|}
\hline Organoleptic parameters & Colour & Savour & Odour & Attribute \\
\hline Identified wells & Clear & Without savour & $\begin{array}{c}\text { Odourless, } \\
\text { sometimes leaf } \\
\text { odour }\end{array}$ & $\begin{array}{c}\text { Clean and drinkable, } \\
\text { becomes a little turbid in } \\
\text { dryness }\end{array}$ \\
\hline Dogbo Well & $\begin{array}{l}\text { Very clear } \\
\text { and limpid }\end{array}$ & Without savour & Odourless & $\begin{array}{c}\text { Very clean, fresh, } \\
\text { drinkable }\end{array}$ \\
\hline Malènou well & Clear & Without savour & Odourless & Clean and drinkable \\
\hline Mosque Well & Clear & Without savour & Odourless & Clean and drinkable \\
\hline Imam Well & Clear & Without savour & Odourless & Clean and drinkable \\
\hline
\end{tabular}

Source: Results of investigation, May 2013

It appears from the analysis of the table that people qualified clean and drinkable water from well that they drank. However, drinking water for domestic use is subject to law requirements in the aim to protect the health of consumers and make it drinkable. Among the regulations, we can mention:
- WHO drinking water quality guidelines (third revised edition in 2004);

- Quality standards of drinking water in Benin.

Waterborne diseases: According to surveyed people, the common water

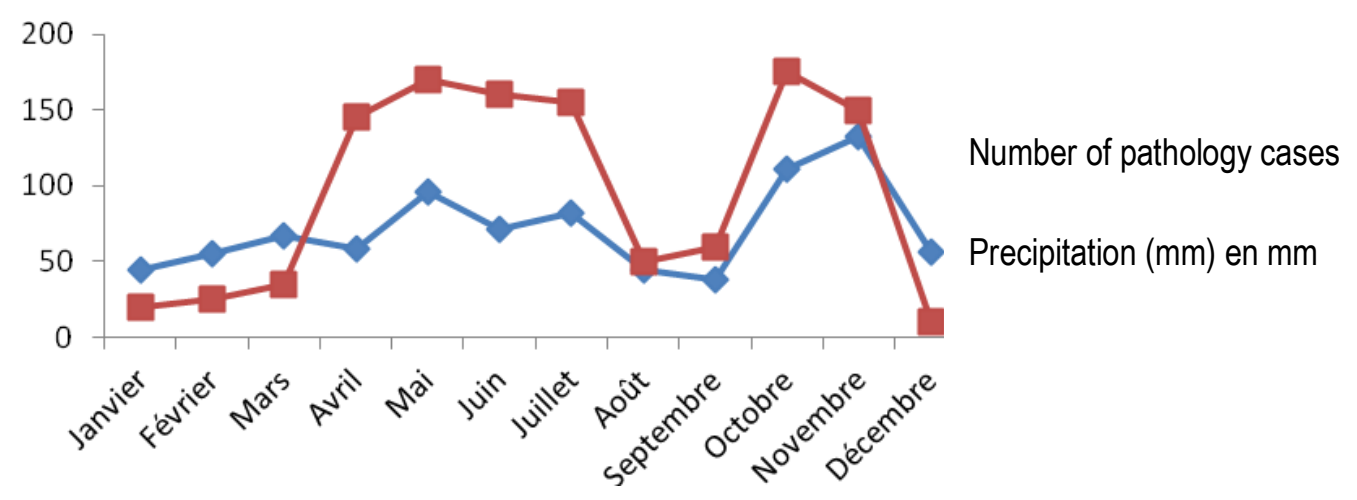

Figure 3: Monthly rhythm of rains and waterborne pathologies from 2010 to 2013

Source: Asecna and centre of health of Aholouyèmè

Figure 3 shows that during 2010 to 2013 , a low rainfalls (December, January, February, August, and September) corresponded to few number of cases of waterborne pathologies whose maximum was 55 cases recorded in February and December. In the same way, an increase of rainfalls (April to July, October to November) corresponded to an increase in the number of cases of waterborne pathologies. The maximum of cases recorded was 133. That was recorded in November. That phenomenon could be explained by the infiltration of faeces in the wells. The faeces would be drained by surface water. Finally, waterborne pathologies were well correlated with precipitations.

Analysis and comment of laboratory results: It was to search some microbiological parameters such as livable germs, total and faecal coliforms, Escherichia Coli, faecal streptococci and the $\mathrm{pH}$, which are physical and chemical parameters very useful in microbiology. The set of all the results obtained at each well are summarized in Table 2. 

commune of Sèmè-Kpodji (BENIN, West Africa)

Table2: Summary of microbiological results of the water samples from various wells

\begin{tabular}{|l|c|c|c|c|c|c|}
\hline & $\begin{array}{c}\text { livable } \\
\text { germs } \\
\text { (UFC/mL) }\end{array}$ & $\begin{array}{c}\text { Total Coliform } \\
\text { (UFC/100mL) }\end{array}$ & $\begin{array}{c}\text { faecal } \\
\text { Coliforms } \\
\text { (UFC/100mL) }\end{array}$ & $\begin{array}{c}\text { Escherichia } \\
\text { coli } \\
\text { (UFC/100mL) }\end{array}$ & $\begin{array}{c}\text { faecal } \\
\text { Streptococci } \\
\text { (UFC/100mL) }\end{array}$ & pH \\
$\begin{array}{l}\text { Well and required } \\
\text { criteria (national } \\
\text { and WHO standard) }\end{array}$ & & & & & & \\
\hline $\begin{array}{l}\text { National/WHO } \\
\text { standard }\end{array}$ & 50 & Absence & Absence & Absence & Absence & $6.5-$ \\
\hline malenou Well & $65.10^{1}$ & 200 & 400 & 100 & $110.10^{2}$ & 7.19 \\
\hline dogbo well & $57.10^{2}$ & $45.10^{2}$ & $45.10^{2}$ & $<1$ & $11010^{2}$ & 6.84 \\
\hline Martin well & $45.10^{3}$ & $<1$ & $<1$ & $<1$ & $10^{3}$ & 7.02 \\
\hline mosque well & $52.10^{2}$ & $11.10^{3}$ & $25.10^{2}$ & $<1$ & $46.10^{2}$ & 7.08 \\
\hline imam well & $4.10^{2}$ & $14.10^{3}$ & $<1$ & $<1$ & $110.10^{2}$ & 7.15 \\
\hline
\end{tabular}

Legend: Black: value required by the national/WHO standard. Red: value beyond the standard. Green: value within the standard (acceptable value)

Source: Results of analysis of laboratory. September 2013

Livable germs: The enumeration of livable gems (photo 2), commonly called the total flora, is an index for general microbiological status of the samples. A high number of livable germs (Figure 4) results often in contamination that comes from storage and water conservation.

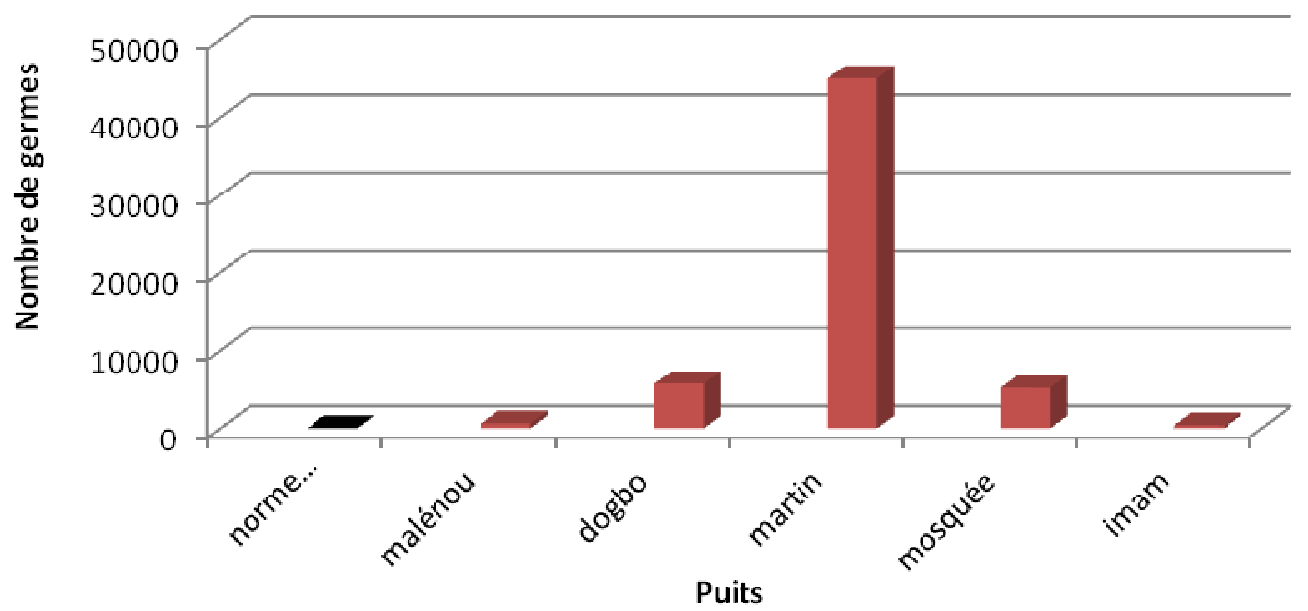

Figure 4: Variation of livable germs per well 


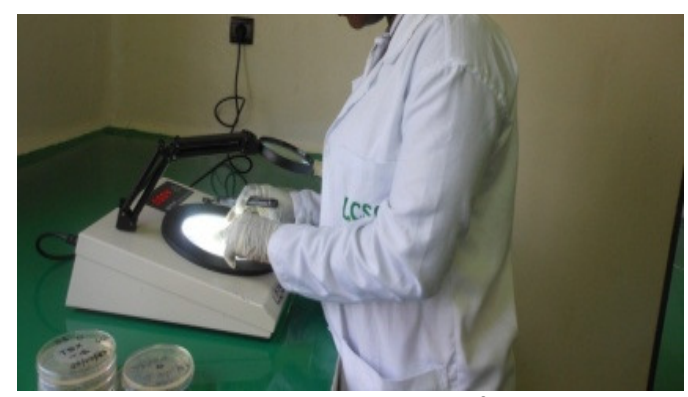

Photography 2: counting of colonies

Camera work: TCHIBOZO, August 2013

The analysis of the results showed that all the water samples tested contained more viable germs than the value required by national / WHO standard (50UFC / ml). As all those germs are from the environment, their high rate (Figure 4) could be explained by the lack of coverage for the majority of the wells. The only well (mosque well) with cover is not regularly covered by the population after use.

Total coliforms: Total coliforms are rod-shaped bacteria, aerobic or anaerobic having beta-galactosidase enzyme for the hydrolysis of lactose at $35^{\circ} \mathrm{C}$. The main genera included in the group are Citrobacter, Enterobacter, Escherichia, Klebsiella and Serratia. Almost all species are non-pathogenic and do not represent a direct risk for health (Edberg et al. 2000; WHO / UNICEF. 2000) except some stocks of Escherichia coli (E. coli) and rare opportunistic pathogenic bacteria. Note that those germs are used for a long time as an indicator of microbial quality of water because they can be indirectly associated with faecal pollution. The presence of total coliforms in water or their exceeding according to standards does not necessarily imply a risk for public health. Indeed, most species of this group are found naturally in soil or vegetation (Babadjidé, 2007). Some species that are rarely found in the faeces can multiply in drinking water like Serrati fonticola (WHO / UNICEF, 2000). The health risk linked directly to the presence of bacteria of total coliform group is low some strains of $E$. coli. The Figure 5 shows the variation of germs in the sampled wells.

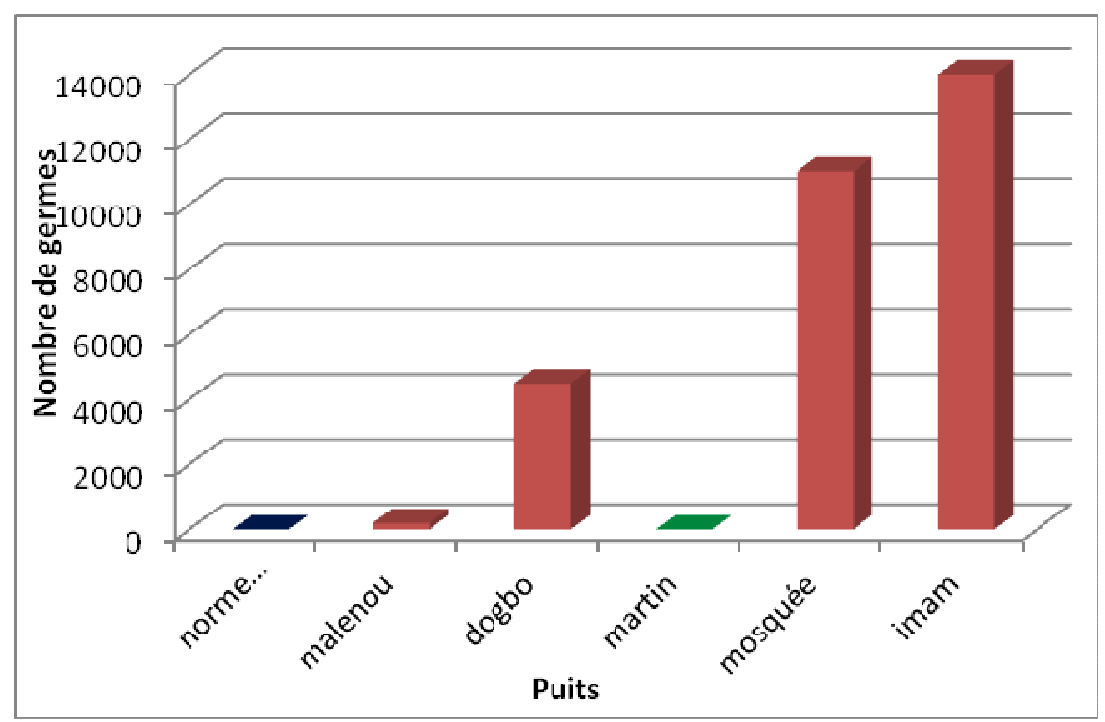

Figure 5: Variation of the total coliforms per well

According to the figure $5,80 \%$ of water samples contained a high number of total coliforms contrary to the requirements of National/WHO Standard. Only "martin well" is acceptable with respect to this microbiological parameter. That observation lead to suspect faecal pollution of wells analyzed.

Faecal Coliforms: Faecal coliforms or thermotolerant coliforms are a subgroup of total coliforms. They are able 
to ferment lactose at a temperature of $44.5^{\circ} \mathrm{C}$. The species frequently associated with this bacterial group is Escherichia coli. The interest of the research of those germs in water lies in the fact that their survival in the environment is generally equivalent to that of bacterial pathogens and their density is generally proportional to the degree of pollution from faeces (Babadjidé 2007). They also detect faecal contamination from such polluted water in canalisation and groundwater. Thus, their presence in treated water is suspect of faecal contamination. On the other hand, the majority of faecal coliforms found in source waters that have been more treated (flocculation, sedimentation, filtration and chlorination) belong to species that do not have such an important pathogenic strains such as Klebsiella pneumoniae found in the natural environment. Figure 6 shows the variation of the germ.

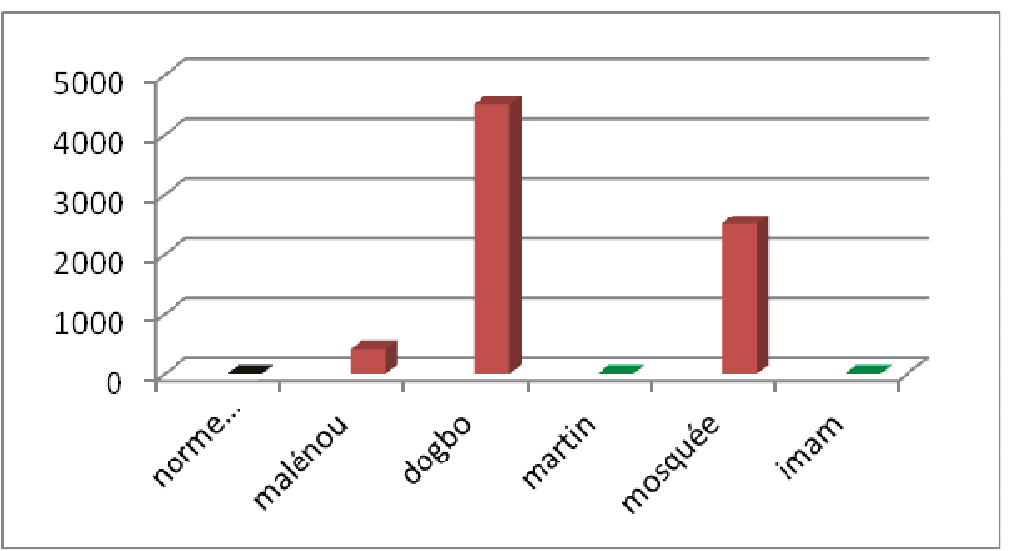

Figure 6: variation of the faecal coliforms per well

Analyzing Figure $6,60 \%$ of sampled waters contained a high number of faecal coliforms. Therefore, they did not meet the criteria of national/WHO standard (absence/100ml). The presence of those germs at a high number in sampled water from wells called "malènou", "dogbo", "mosque" may be due to faecal contaminations that come from the unhealthy use of these wells by population (mosque malènou) and the unhealthy environment by animal faeces or men who would be infiltrated into the well (Dogbo).
E. Coli: E. coli is part of the faecal coliform group and is the only member of that group found exclusively in faeces of humans and animals. The figure 7 shows the variation of $E$. coli in each well. It appears from the analysis of Figure 7 that "malènou well" contained $100 \mathrm{UFC} / 100 \mathrm{ml}$ of E. coli while the germ is absent in the other four (4) wells. Plate 1 shows the identification of $E$. coli by two methods for the confirmation of the presence or absence of this organism in the samples.

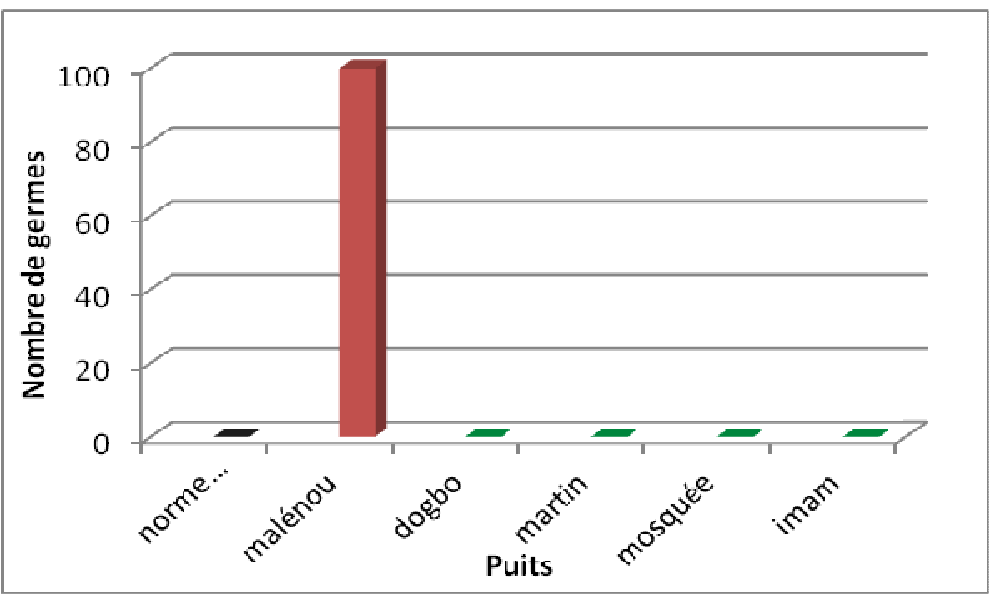

Figure 7: Variation of $E$. coli by well 


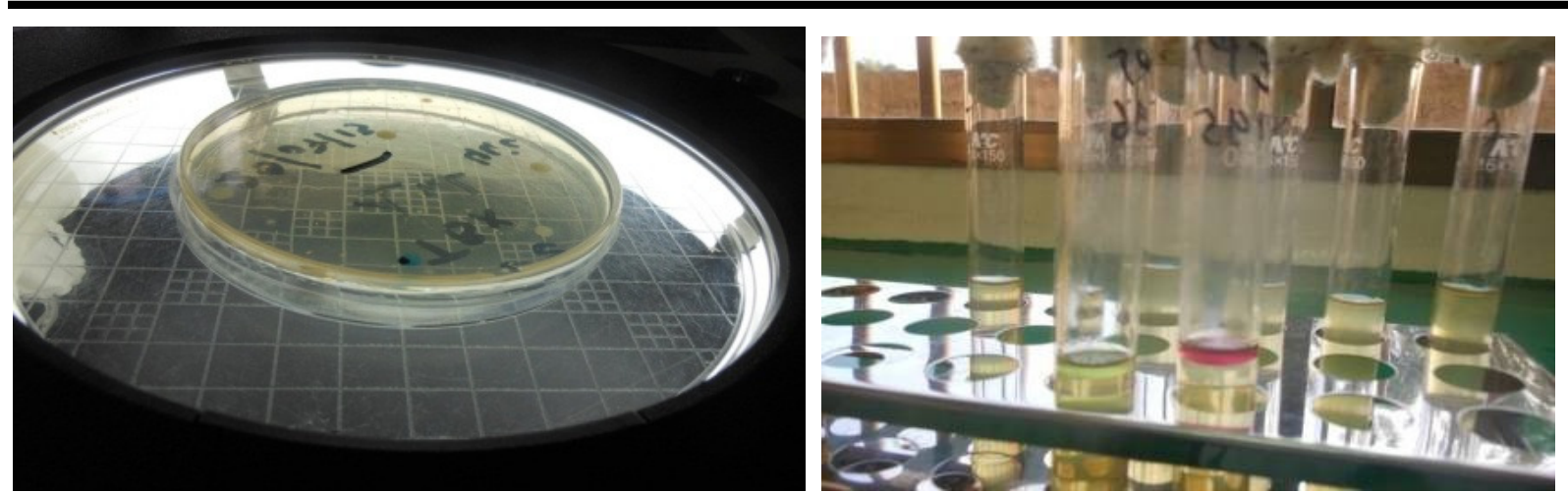

Plate 1: Identification of E. coli on TBX (left) and by the test of Mackensie (right).

Camera work: DEGBENOU. August 2013

The presence (Plate 1) of this germ in "malènou well " denotes a public health problem in the district of Aholouyèmè. Indeed, the presence of this organism in water indicates not only recent contamination of contents faeces, but also the possible presence of bacteria, viruses and protozoa. The detection of $E$. coli in the water should lead to the immediate release of a boil water and adoption of corrective measures.

Streptococci faecal: The faecal streptococci also called serological streptococci of group D of the classification of
Lancefield are germs often found in the gastrointestinal tract of humans and many animals. They have a notable resistance to disinfectants. That quality makes them indicators of faecal contamination in aquifers (ground water) and a privileged tool for the evaluation of the effectiveness of water treatment (WHO / UNICEF, 2000). Further, studies in the US have demonstrated their usefulness to highlight faecal contamination of groundwater (US EPA, 2000a). Figure 8 shows the variation of this germ in samples from wells.

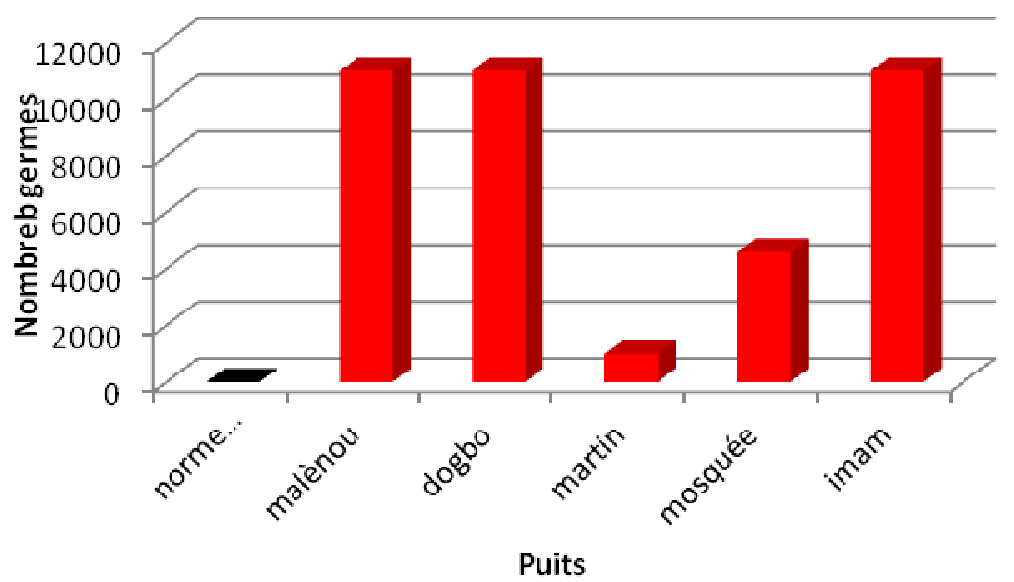

Figure 8: Variation of faecal streptococci by well

The analysis of Figure 8 show that $100 \%$ of our samples from well water contained high numbers of faecal streptococci while the national standard/WHO requires that they must be absent in $100 \mathrm{ml}$ of water sample. The remarkable presence of these germs means faecal pollution from those wells by the population after use or by the phenomenon of infiltration of human or animal faeces. In addition, their presence in large numbers though they are faecal coliform may be explained by the fact that those streptococci of the Lancefield classification compared to coliforms (including Escherichia coli) are more resistant to difficult environmental conditions and persist longer in water (Gleeson and Gray, 1997).

pH: Analysis of Table II shows that all the water samples tested have a $\mathrm{pH}$ that respects national / WHO standard. 


\section{CONCLUSION}

The results of microbiological (bacteria) analyze show that the water from the five (5) wells sampled is unfit for human drinking. All collected water contains faecal streptococci beyond the national standard $(\mathrm{no} / 100 \mathrm{ml})$, four out of five (4/5) wells contain coliform beyond the norm. The situation is even more serious at the wellcalled "malènou" where analysis revealed that the water from this well contained the most offending germ, which is

\section{REFERENCES}

Babadjide (2007): Endogenous management of water and 3rd tat of public health of the district of Bèssè. Memory of DEA/FLASH/UAC 102p.

Edberg. SC. EW Rice. RJ Karlin et MJ Allen (2000): Escherichia coli: the best biological drinking water indicator for public health protection. Journal of Applied Microbiology. 88: 106S-116S.

Gleeson. C. And Gray. N. (1997): The Coliform Index and Waterborne Disease E. and FN Spon. London. pp194

INSAE. (2002): Third Census General of the Population and the Dwelling; analyze results. volume 2: dynamics of the population. $127 \mathrm{p}$.

MMEH. (2005): National strategy of the supply drinking water in rural medium of the Benign 2005-2015. $35 p$.

Slansky M. 1995: Geological investigation and hydrogeology of low Dahomey. Federal Government of the AOF.

Sohounou M. (2012): Approach kind in the management integrated of the water resources into Togoudo
E. coli. This leads to suspect recent faecal pollution due to infiltration of faeces in the wells especially during the rainy season and due to lack of hygiene by the people after relieving themselves. Thus, the consumption of such water can cause gastroenteritis or epidemics in the area. The effects of the consumption of a poor bacteriological quality water are short-term and affect often a significant number of people.

in the commune of Allada. professional memory of maitrise. UAC/FLASH. 81p.

U.S. Environmental Protection Agency. (2000a) : Public Comment Draft. "Proposed Guidance on Cumulative Risk Assessment of Pesticide Chemicals that Have a Common Mechanism of Toxicity;" June 22. 2000. 65 FR 40644. Office of Pesticide Programs. Office of Prevention. Pesticides. and Toxic Substances. Washington. DC.

UNO. (2005): water source of life. 2005-2015.

WHO. (1994): Directives of quality for the drink water. Geneva. 202p

WHO/UNICEF. 2000: Report/ratio on the evaluation of the world situation of the provisioning water and the cleansing in 2000.0MS/UNICEF. 80p.

Yelognisse C L H. H. (2007): Improvement of the conditions of access to a drinking water for the drink water in the rural mediums of the benign one: study of the local practices. Masters paper in sciences of the environment. 105p. 